\title{
REPRODUCTIVE ASPECTS OF CYPHOCHARAX VOGA (HENSEL) FROM CUSTÓDIAS LAGOON, RIO GRANDE DO SUL, BRAZIL (CHARACIFORMES, CURIMATIDAE)
}

\author{
Lúcia Cabral Schifino ${ }^{1}$ \\ Clarice Bernhardt Fialho ${ }^{2}$ \\ José Roberto Verani ${ }^{3}$
}

\begin{abstract}
The aim of this study was to analyse the reproductive period, fecundity and the size of the first gonadal maturation of Cyphocharax voga (Hensel, 1869) of Custódias Lagoon, state of Rio Grande do Sul, Brazil. The specimens (293 males and 247 females) were collected monthly, during the period between October 1994 and September 1995. The reproductive period took place from early winter until the end of spring. The average absolute fecundity was 36608 oocytes. The size of the first gonadal maturation was estimated in 121 and $128 \mathrm{~mm}$ for males and females respectively.

KEY WORDS. Curimatidae, Cyphocharax voga, fecundity, reproduction
\end{abstract}

The Curimatidae family has its geographical distribution restricted to the South America. According to VARI (1989), its representatives live in a great variety of fresh water environments distributed from the Pacific Coast of the Isthmus of Panamá to the south of Buenos Aires.

The species of this family, objective of the present study, is Cyphocharax $\operatorname{vog} a$ (Hensel, 1869), popularly known in Rio Grande do Sul as "Biru". Its distribution includes the Paraguay rivers system, low Paraná until the hidrographic systems of the coastal rivers from the south of Brazil, Uruguay and Argentina (VARI 1988).

Studies of the reproduction of some species of Curimatidae can be found in AZEVEDo et al. (1938), Nomura \& TAVEIRA (1979), NomURA \& HAYASHi (1980), TAPHORN \& LILYSTRON (1983), CARVALHO (1984), MORAES et al. (1984) and ROMAGOSA et al. (1984). It must be pointed out the works on C. voga carried out by HARTZ \& BARBIERI (1994) and HARTZ et al. (1994) in isolated lagoons of Rio Grande do Sul.

The present study aims to establish, for C. voga from Custódias Lagoon, the reproduction period, fecundity and size of the first gonadal maturation.

1) Curso de Pós-graduação em Ecologia, Universidade Federal do Rio Grande do Sul. Avenida Bento Gonçalves 9500, 91501-970 Porto Alegre, Rio Grande do Sul, Brazil.

2) Departamento de Zoologia, Laboratório de Ictiologia, Universidade Federal do Rio Grande do Sul. Avenida Paulo Gama, 90046-900 Porto Alegre, Rio Grande do Sul, Brazil.

3) Departamento de Hidrobiologia, Universidade Federal de São Carlos. Caixa Postal 676, 13560-000 São Carlos, São Paulo, Brazil.

Revta bras. Zool. 15 (3): 767 - 773, 1998 


\section{MATERIALS AND METHODS}

A total of 540 specimens (293 males and 247 females) were collected monthly in Custódias Lagoon, Tramandaí, Rio Grande do Sul $\left(30^{\circ} 01^{\prime} \mathrm{S}, 50^{\circ} 10^{\prime} \mathrm{W}\right)$ during the period from October 1994 to September 1995.

The Custódias Lagoon is classified as a shallow lagoon with a mean depth of $1.10 \mathrm{~m}$ and occupying an area of $9.58 \mathrm{~km}^{2}$ receiving salt influence via Armazém Lagoon.

The specimens capture was made by four sets of fishing nets. Each set comprised seven nets with distance between knots of 1.2, 2.0, 3.0, 3.5 and $4.0 \mathrm{~cm}$. For each individual captured the total length in millimetres (Lt), the total weight $(\mathrm{Wt})$ in grams, sex and stage of gonadal maturation have been recorded.

The identification of the gonadal maturation stages was carried out taking into account macroscopic aspects like colour, vascularization, flaccidity, size in relation to the abdominal cavity and oocytes visualization. The following maturation stages were defined: I) immature; II) in maturation; III) mature; IV) semi-exhausted and $\mathrm{V}$ ) exhausted.

The female gonads used for fecundity analysis remained in Gilson's solution (VAZZOLER 1981) until the complete detachment of the ovocytes from the conjunctive tissue could be observed. The material was kept in $70 \%$ alcohol and sampled with a Stempell pipette with $2,5 \mathrm{ml}$ capacity.

The reproduction period was established according to the methodology proposed by SANTOS (1978). The relative frequency distribution of each gonadal maturation stage have been analysed as well as the monthly mean values of the gonadossomatic index (GSI) during the studied period.

The determination of the size of first gonadal maturation was based in the frequency distribution of adult specimens in classes of total length corresponding to $50 \%$ frequency in adult individuals (Lpm) (SANTOS 1978). The resulting curve was fitted to the equation:

$$
F r=1-\left(e^{-\infty L t^{b}}\right)
$$

\section{RESULTS AND DISCUSSION}

The monthly mean values of the gonadossomatic index were plotted in order to show its variation during the studied period (Fig. 1). The occurrence of sazonality of the reproductive period of the specie can be noticed, as confirmed by chy-squared test.

The reproductive period is long, beginning in winter and lasting to the end of spring. This trend is reinforced by the high frequency of mature individuals during September and October (Fig. 2).

The Curimatidae species seems to have a long reproductive period as a characteristic, since the same results have been found by other authors (AZEVEDO et al. 1938; MORAES et al. 1984; ROMAGOSA et al. 1984; CARVALHO 1984; HARTZ \& BARBIERI 1994). 


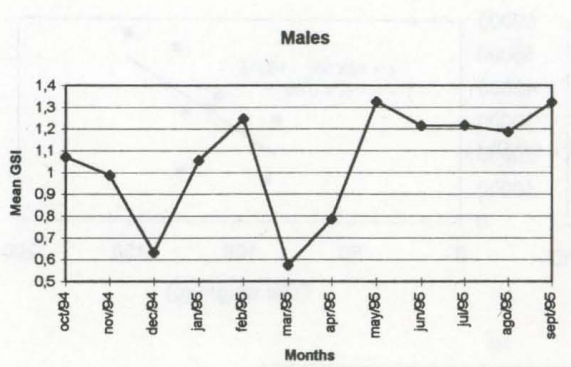

Females

Males

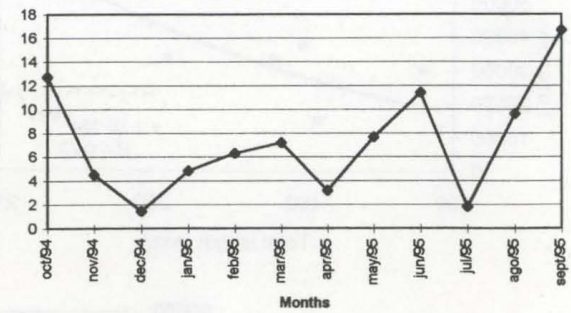

Fig. 1. Monthly variation of the mean values of the gonadossomatic index (GSI) for males and females of Cyphocharax voga from october/1994 to september/1995.

Males

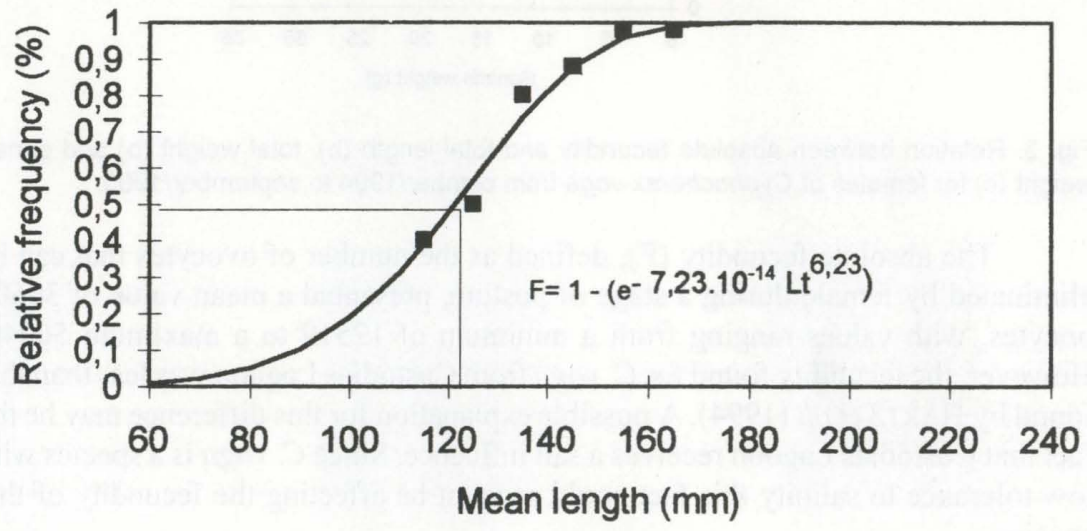

Females

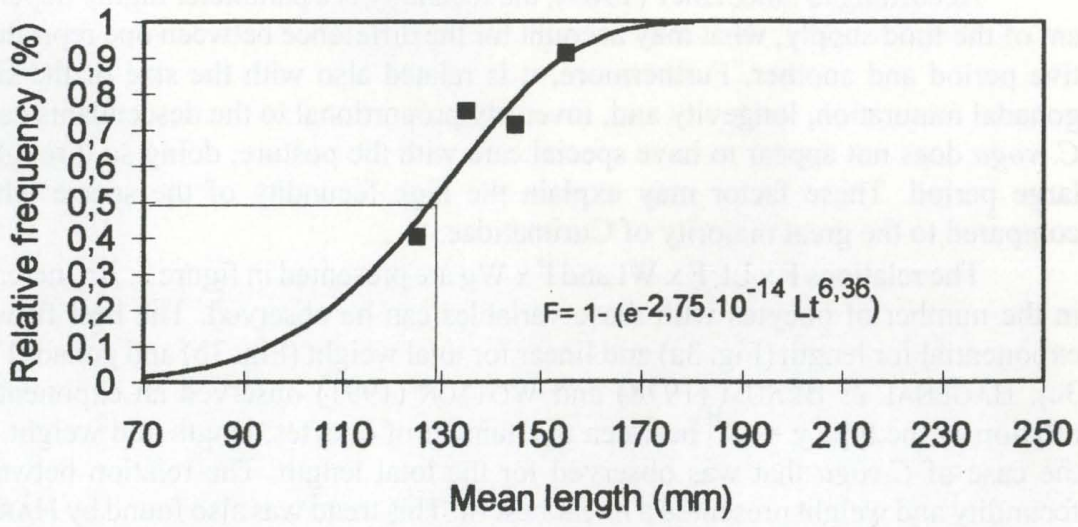

Fig. 2. Monthly distribuition of the relative frequencies of the gonadal maturation stages for males and females of Cyphocharax voga of Custódias lagoon during the period from october/1994 to september/1995. 
(a)

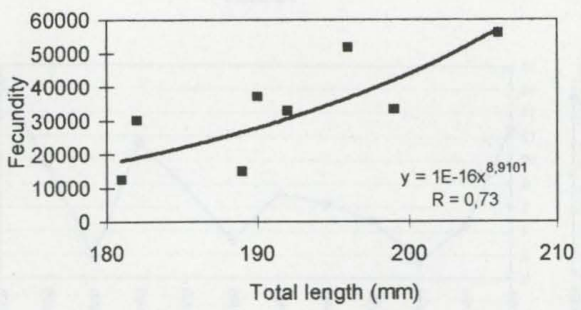

(b)

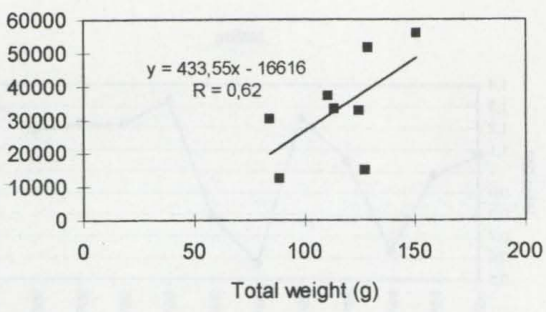

(c)

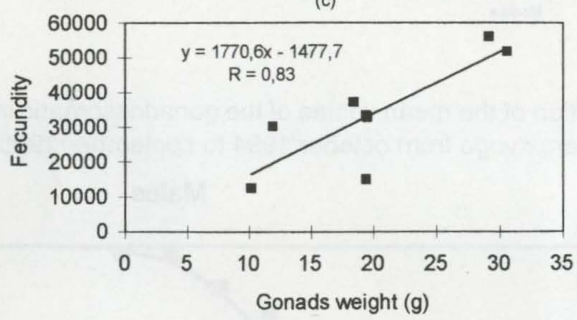

Fig. 3. Relation between absolute fecundity and total length (a), total weight (b) and gonad weight (c) for females of Cyphocharax voga from october/1994 to september/1995.

The absolute fecundity (F), defined as the number of ovocytes that can be eliminated by female during a stage of posture, presented a mean value of 36608 oocytes, with values ranging from a minimum of 12519 to a maximum 56040 . However, the fecundity found for $C$. voga from Custódias Lagoon was less than that found by HARTZ et al. (1994). A possible explanation for this difference may be the fact that Custódias Lagoon receives a salt influence. Since C. voga is a species with low tolerance to salinity this fact could account be affecting the fecundity of this species.

According to NIKOLSKY (1969), the fecundity is a parameter highly dependent of the food supply, what may account for the difference between one reproductive period and another. Furthermore, it is related also with the size of the first gonadal maturation, longevity and, inversely proportional to the descendants care. C. voga does not appear to have special care with the posture, doing so through a large period. These factor may explain the high fecundity of the specie when compared to the great majority of Curimatidae.

The relations $\mathrm{F} x \mathrm{Lt}, \mathrm{F} x \mathrm{Wt}$ and $\mathrm{F} x \mathrm{Wg}$ are presented in figure 3 . An increase in the number of oocytes with these variables can be observed. The best fit was exponential for length (Fig. 3a) and linear for total weight (Fig. 3b) and gonad (Fig. 3c). BAGENAL \& BRAUM (1978) and WotTON (1991) observed an exponential relation of the type $y=a x^{b}$ between the number of oocytes, length and weight. In the case of C.voga that was observed for the total length. The relation between fecundity and weight presented a linear best fit. This trend was also found by HARTZ et al. (1994). According to these authors a small variation in size for the analysed fish could result in a linear trend. Although the variation in length for the analysed females was small (181 to $206 \mathrm{~mm}$ ) the potencial trend was found. ROMAGOSA et 
al. (1984) have found a large variation in fecundity for Curimatus gilberti (Quoy \& Gaimard, 1824) sample of same length or weight; WoTTON (1991) considered this variation as a consequence of the interaction of genetic and ambiental factors. In spite of the variation encountered it is possible to observe that the fecundity of C. voga is more related to the gonads weight. The same result has been found by CARVAlHo (1984) for Curimata (Potamorhina) pristigaster (COPE 1878), RoMAGOSA et al. (1984) for C. gilberti and by HARTZ et al. (1994) for C. voga.

Using figure 4, an estimate for the first gonadal maturation of 121 millimetres for males and 128 millimetres for females has been made. From 170 and 180 millimetres all males and females respectively, are ready for reproduction.

The sizes of the first gonadal maturation ( $\mathrm{Lpm}$ ) found for males and females of $C$. voga in Custódias Lagoon were smaller than those found by HARTZ et al. (1994) in Emboaba Lagoon. Possibly, this parameter, as well as the total length of the individuals, could be affected by the salinity, since individuals in physiological stress, would be allocating more energy to their survival.
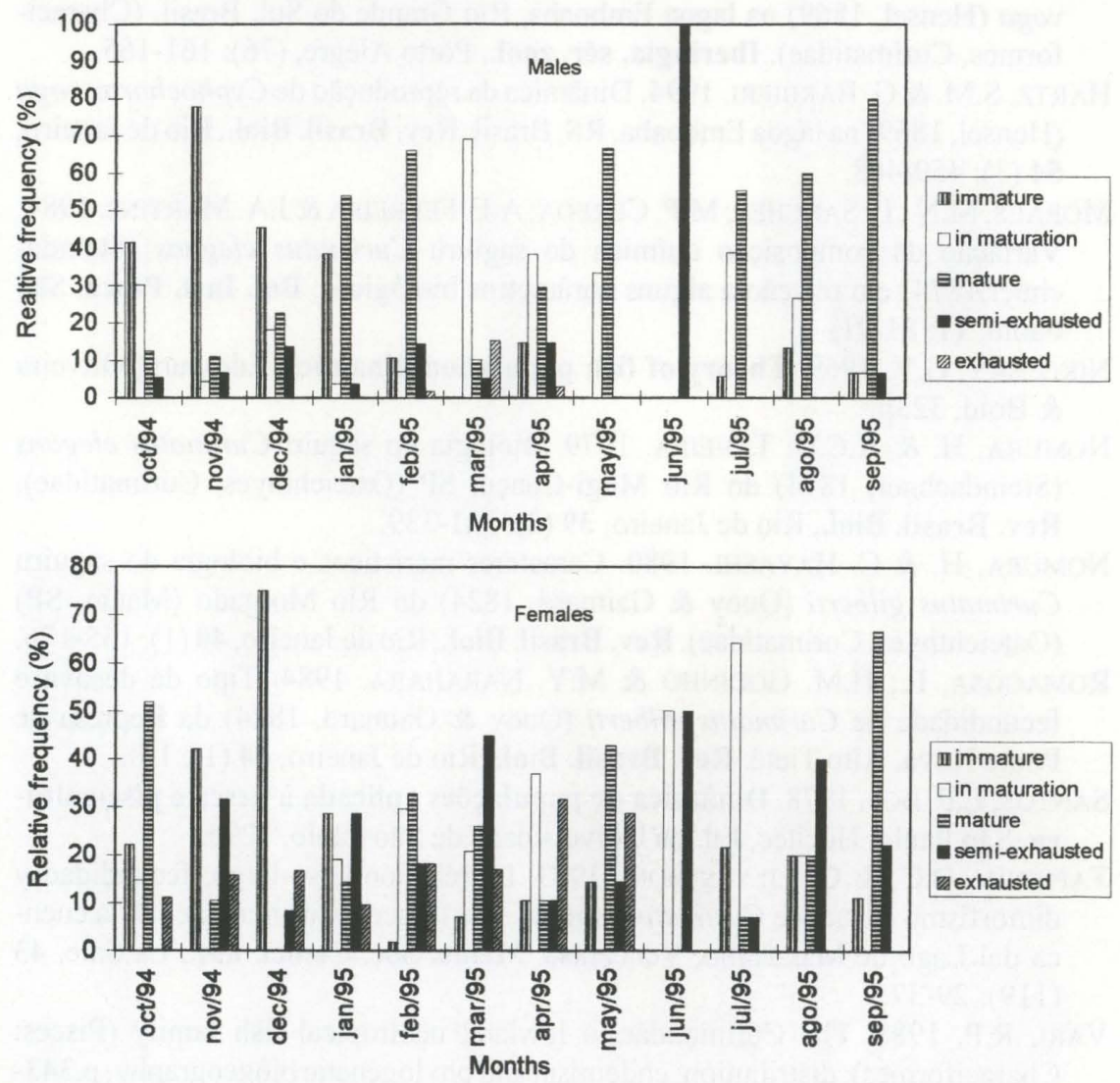

Fig. 4. Distribuition of the relative frequencies of adult males and females of Cyphocharax voga, by total length classes, during the period from october/1994 to september/1995. 
ACKNOWLEDGEMENTS. We thank Prof. Dr. José Schifino for all the help, suggestions and encouragement. Pos-graduate Course of Ecologia, Federal University of Rio Grande do Sul, for laboratory facilities. Financial support was provided by the CAPES.

\section{REFERENCES}

Azevedo, P.; M.V. Dias \& B.B. VieiRA. 1938. Biologia do sagüiru (Characidae, Curimatidae). Mems. Inst. Osvaldo Cruz, Rio de Janeiro, 4: 481-553.

Bagenal, T. \& E. Braum. 1978. Eggs and early life history, p.165-201. In: T. BAGENAL (Ed). Methods for assessment of fish production in fresh-waters. Oxford, Blackwell Sc. Publ.

CARVAlHO, F.M. 1984. Aspectos biológicos e ecofisiológicos de Curimata (potamorhina)pristigaster, um Characoidei neotrópico. Amazoniana, Manaus, 8 (4): 525-539.

HartZ, S.M.; A.G. MARTins \& A.C. Peret. 1994. Fecundidade de Cyphocharax voga (Hensel, 1869) na lagoa Emboaba, Rio Grande do Sul, Brasil. (Characiformes, Curimatidae). Iheringia, sér. zool., Porto Alegre, (76): 161-165.

HARTZ, S.M. \& G. BARBIERI. 1994. Dinâmica da reprodução de Cyphocharax voga (Hensel, 1869) na lagoa Emboaba, RS, Brasil. Rev. Brasil. Biol., Rio de Janeiro, 54 (3): 459-468.

MoraEs, M.N.; L. SANCHEZ; M.P. CEREDA; A.E. FerReIRA \& J.A. MARTINS. 1984. Variação da composição química do sagüiru Curimatus elegans (Steindachner,1874) em relação a alguns parâmetros biológicos. Bol. Inst. Pesca, São Paulo, 11: 81-91.

NIKOLSKY, G.V. 1969. Theory of fish population dinamics. Edinburg, Oliveira \& Boid, 323p.

Nomura, H. \& A.C.D. TAVEIRA. 1979. Biologia do saguiri Curimatus elegans (Steindachner, 1874) do Rio Mogi-Guaçu, SP (Osteichthyes, Curimatidae). Rev. Brasil. Biol., Rio de Janeiro, 39 (2): 331-339.

NOMURA, H. \& C. HAYASHI. 1980. Caracteres merísticos e biologia do saguiru Curimatus gilberti (Quoy \& Gaimard, 1824) do Rio Morgado (Matão, SP) (Osteichthyes, Curimatidae). Rev. Brasil. Biol., Rio de Janeiro, 40 (1): 165-176.

Romagosa, E.; H.M. Godinho \& M.Y. NARAHARA. 1984. Tipo de desova e fecundidade de Curimatus gilberti (Quoy \& Gaimard, 1824) da Represa de Ponte Nova, Alto Tietê. Rev. Brasil. Biol., Rio de Janeiro, 44 (1): 1-8.

SANTOS, E.P. DOS. 1978. Dinâmica de populações aplicada à pesca e piscicultura. São Paulo, Hucitec, Ed. da Universidade de São Paulo, 129p.

TAPHORN, D.C. \& G. LiLYESTROM. 1983. La relación peso-largo, fecundidad y dimorfismo sexual de Curimatus magdalenae (Pisces, Curimatidae) de la cuenca del Lago de Maracaibo, Venezuela. Mems. Soc. Cienci. nat., La Sale, 43 (119): 29-37.

VARI, R.P. 1988. The Curimatidae, a lowland neotropical fish family (Pisces: Characiformes); distribution, endemism and phylogenetic biogeography, p.343377. In: Proceedings of a Workshop on Neotropical Distribution Patterns. Rio de Janeiro, Academia Brasileira de Ciências. 
1989. A filogenetic study of the neotropical characiform family Curimatidae (Pisces: Ostariophysi). Smithson. Contrib. Zool. 471: 1-71.

VAZzoler, A.E.A.M. 1981. Manual de métodos para estudos biológicos de populações de peixes. Reprodução e Crescimento. CNPq, Programa Nacional de Zoologia, Brasília, 108p.

WotTon, R.G. 1991. Ecology of Teleost Fishes. London, Chapman \& Hall, 404p.

Recebido em 25.IV.1997; aceito em 17.VIII.1998. 